\title{
The Design of Technological Instructions for an Assembling the Aircraft Engine
}

\author{
Martin Novák \\ Department of Air Transport, \\ Department of Air Transport, Faculty of Transportation \\ Sciences, Czech Technical University \\ Horská 3, Praha 2, 128 03, Czech Republic \\ novakm@fd.cvut.cz
}

\author{
Petr Daňko \\ Department of Air Transport, \\ Department of Air Transport, Faculty of Transportation \\ Sciences, Czech Technical University \\ Horská 3, Praha 2, 128 03, Czech Republic \\ petr.danko@post.cz
}

\author{
Martin Lukavský \\ Department of Air Transport, \\ Department of Air Transport, Faculty of Transportation Sciences, Czech Technical University \\ Horská 3, Praha 2, 128 03, Czech Republic \\ xlukavsky@fd.cvut.cz
}

\begin{abstract}
This article is about a design of new technological instructions for an aviation industry. The goal of the new technological instructions is to replace the old ones. The old instructions are less clear and less suitable for new workers. A change and an upgrade of the new instructions is shown on the technological instructions for disassembling of free turbine's blades during general overhaul. The free turbine is from the M601 engine. The new instructions should be more efficient and enhanced general overhaul.
\end{abstract}

Keywords - technological instructions, assembling aircraft engine, design of technological instructions, instructions for aviation industry

\section{INTRODUCTION}

The Department of Air Transport closely cooperates with an aviation industry in some areas. One of the areas is a preparation and a production of new documentation that is designed for an assembly line of the engine M601.

Contemporary assembly documentation seems to be very outdated in these days of the digitalization. Because of this a common intention arose for design of new technological instructions in an assembly of aircraft engines.

All assembly of the aircraft engine is a very complicated operation. Especially in a case of a turboprop engine that comes through general overhaul. There is an important combination of some factors that in finally sum have a very important influence not only on a quality of the assembly but also on a behaviour of the engine in the course of its life. One of this factors is a good technical documentation. This article deals with the assembly documentation.

\section{DOCUMENTATION}

The technical documentation is systematically divided complex of graphical, textured and if need another (special) obligatory materials that together permit to realize all phases of a production (for example production of a product, a technological device or a system). Integral part of the technical documentation is also operational, assembly, branch and revision regulations (standards). The regulations must be respected if you want to achieve and stabilize required properties of the product or the device for all time of their planned lifetime.

A scope and a complexity of the technical documentation depends on a construction, required properties and a complexity of the product. The current status of a technical and technological level greatly affects a construction, a method of the preparation and also an archiving of the technical documentation.

\section{THE ASSEMBLY DOCUMENTATION}

It is necessary to write down the assembly documentation (a special type of the technical documentation) in case that the complexity of the product or the device requires to abide the exact procedure during the assembly. Its drawing part contains connecting dimensions and a spatial positioning of the product or the device. The connected or otherwise functionally linked components are pictured simplified. The texture part defines conditions and a procedure of the assembly.

As an example, it can be mentioned the actual technological instruction (figure 1) that describes the free turbine's assembly (a numbering by el. pen on a discus of the free turbine and a blade's description) into the M601E engine for the general overhaul. The second example can be the new 
technological instruction (figure 2 and 3 ) in which the photos from the assembly are inserted. These photos had to be edited or highlighted in relevant programs. The new technological instruction designed for the free turbine's assembly is made according to general demands of this type of the documentation and according to the demands of the aviation industry.

\section{THE DESIGN OF THE TECHNOLOGICAL INSTRUCTION}

The old technological instruction (figure 1) that is mentioned below corresponds to an actual valid version that is used by aircraft workers for the free turbine's assembly.

The form of a processing and a way of technological instruction's division must ensure maximal intelligibility. The text is written by simple from. It must not to be comprehensive because a big quantity of the text can lead to losing attention away from the assembly's operation. This instruction is for workers who have been trained and their experience are sufficient enough to manage the assembly without any help.

There are many reasons for establishing the new type of the technological instructions. To the most important are the fact that a training time for the aircraft assembly workers needs reducing, a possibility to transfer the instruction onto a touchable monitor, a visualization of each steps and a minimization of human mistake during small technical changes of the construction.

\section{THE COMPARISON OF BOTH TYPES OF THE TECHNICAL INSTRUCTION}

A. Advantages of the actual instruction:

- Several operations on one page

- Simple form of the instruction

\section{B. Disadvantages of the actual instruction:}

- Only few information for the aircraft workers with minimal experience

- Unutilized space on the page

- Old form of the instruction

- Worse readability because of the repeated copying and stocking in a paper form

C. Advantages of the new instruction:

- Visualization

- Clarity

- Simplicity

- Independent changing

- Utilization of the free space

- $\quad$ Big facilitation for beginning workers

- Possibility of simple transfer onto the touchable monitor

D. Disadvantages of the new instruction:

- $\quad$ One operation = one page

- Hard preparation

- Time-consuming editing of the photos because of their quality (zooming, highlighting of contours and other important parts)

TABLE 1 THE TRANSLATION OF THE OLD TECHNICAL INSTRUCTIONS (FIGURE 1).

\begin{tabular}{|c|c|c|}
\hline \multicolumn{3}{|c|}{$\begin{array}{l}\text { ENGINE M601E } \\
\text { THE MANUAL FOR THE GENERAL OVERHAUL } \\
\text { The assembly of the free turbine's rotor }\end{array}$} \\
\hline Section No & $\begin{array}{c}\text { TECHNOLOGICAL PROCESS } \\
\text { - work volume }\end{array}$ & Tools, devices, awxiliany material \\
\hline 11. & $\begin{array}{l}\text { You must number the blades } 1-28 \text { for a control of the vibration. You must } \\
\text { write number } 1 \text { and an arrow (figure } 310 \text { ) under the first hinge. The mark } \\
\text { must be done by electronic pen only in section between } \varnothing 111 \text { and } \varnothing 90 \text {. } \\
\text { You must marked the relative position of all assembled parts. }\end{array}$ & $\begin{array}{l}\text { Control device } 100-565-9029 / 01 \\
\text { Counterweight } 400-475-4011 \\
\text { El. pen }\end{array}$ \\
\hline 12. & $\begin{array}{l}\text { The transport must be done with the crate and bearings must be protected } \\
\text { by PVC foil. }\end{array}$ & $\begin{array}{l}\text { Crate } \\
100-747-003101\end{array}$ \\
\hline 13. & $\begin{array}{l}\text { You must control prescribed dimensions } \mathrm{R} \text { between blades before } \\
\text { mounting the locks. }\end{array}$ & $\begin{array}{l}\text { Folic Gauges } 0.5-1.0 \times 100 \\
\text { CSN } 251670\end{array}$ \\
\hline 14. & $\begin{array}{l}\text { You must check the blade's locks according to the M601-P13-09B. } \\
\text { The excess of the blades } \mathrm{h} 3 \text { and dimension } \varnothing 267.6-0.4 \text { must be written } \\
\text { down into assembly list (according to figure } 310 \text { and technical drawing). } \\
\text { The dimension of the highest blade is written down. }\end{array}$ & Control device $200-565-9020 / 03$ \\
\hline $11-06-29$ & \multicolumn{2}{|c|}{$\begin{array}{l}\text { The mounting of blades } \\
\text { Page } 5167\end{array}$} \\
\hline
\end{tabular}




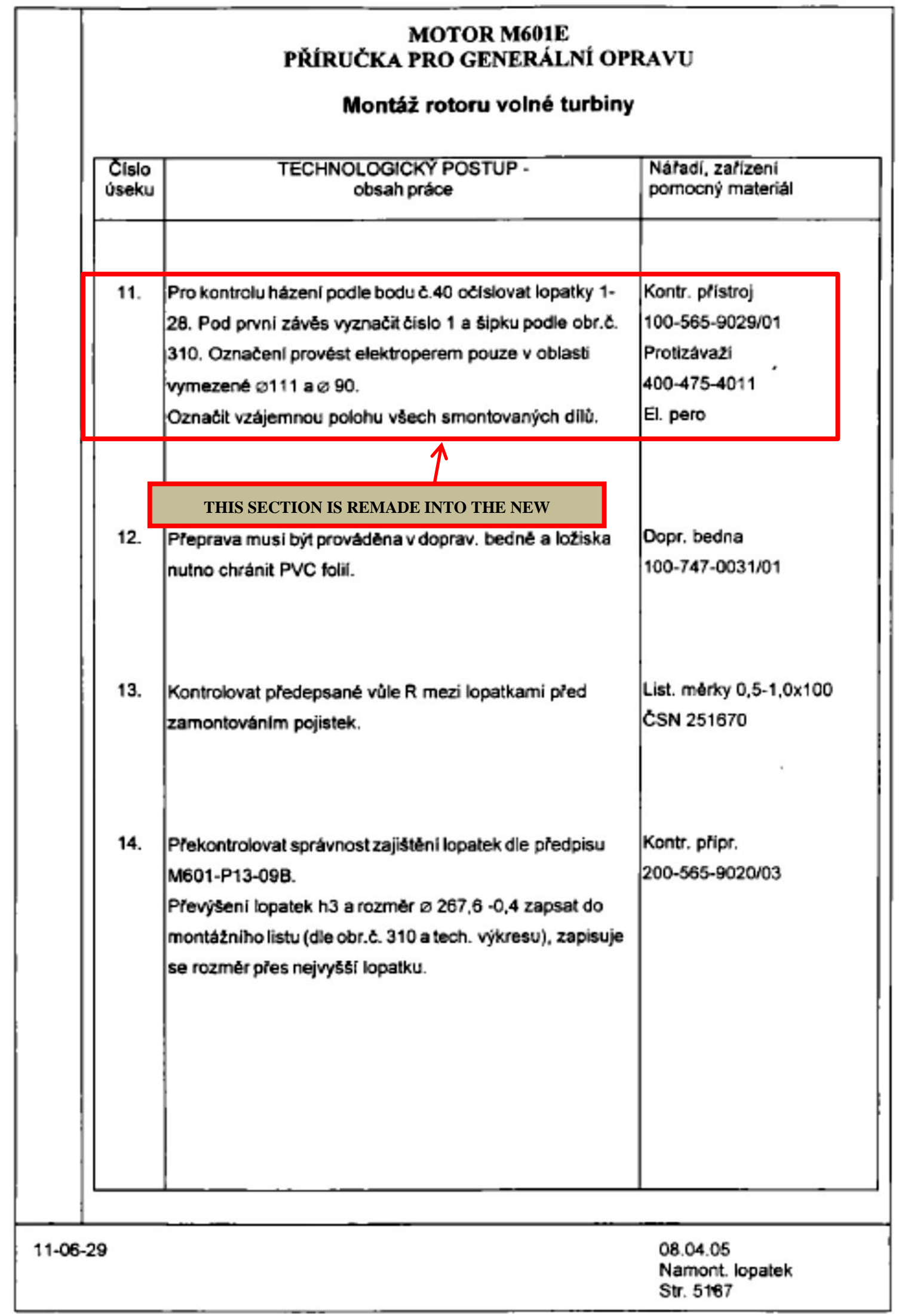

Figure 1 The current technological instructions. The translation of this instructions is in the table 1. 


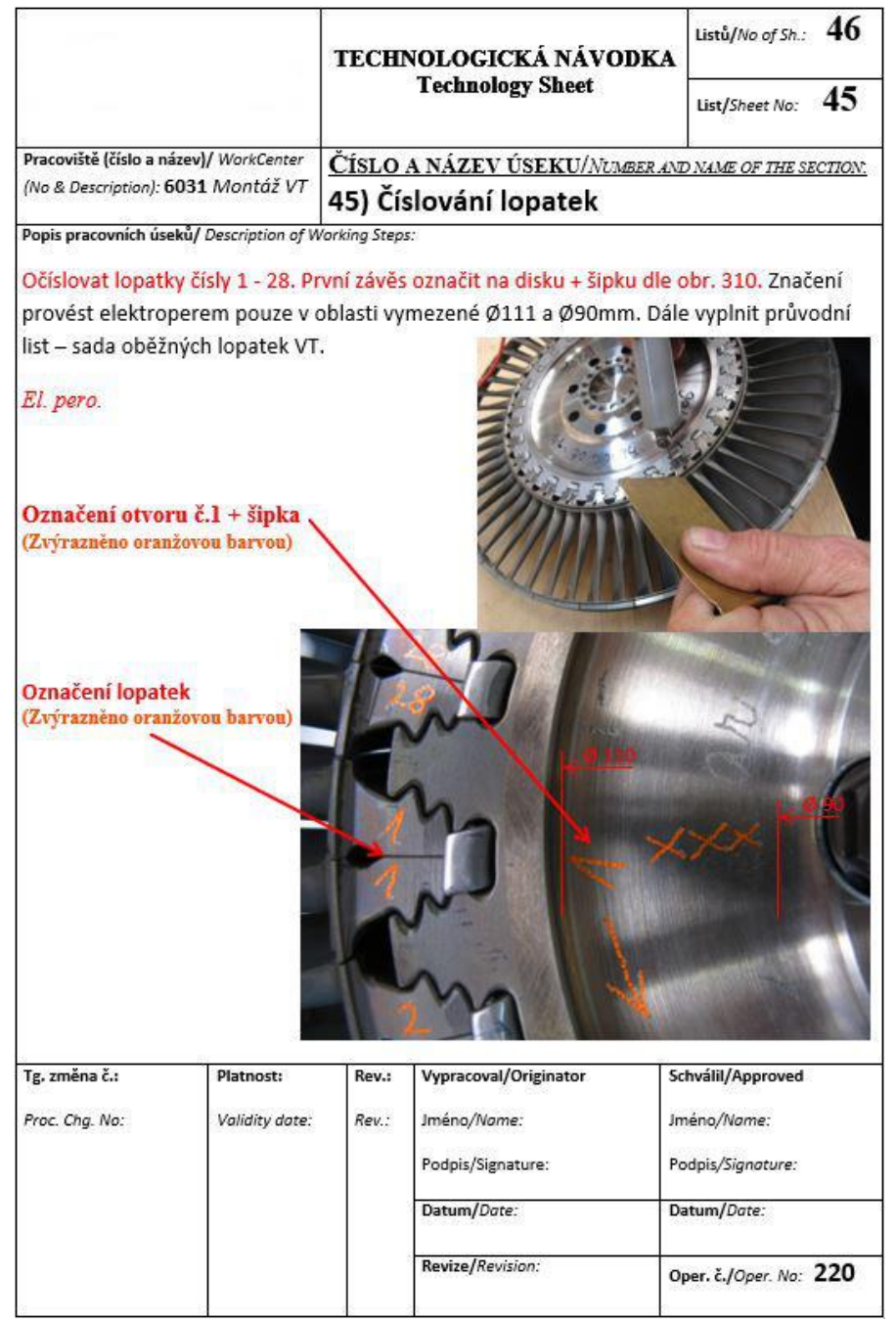

Figure 2 The designed technological instructions in original language.

\section{CONCLUSION}

To reach the most effective preparation of the assembly documentation, it is important to include a big number of factors that can quite quickly be changed in small details. We can mention some of them: worker's experience, the quality of the production and of the supplied parts.

To finish the whole project of the assembly documentation's creation, it will be necessary to listen to all people who take part in the process of production, assembly, disassembly, general overhaul and other processes that are connected with the M601 engine.

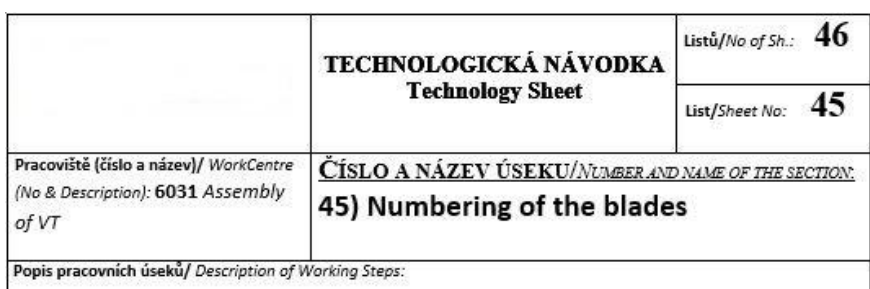

You must number the blades 1-28. The first hinge must be marked 1 and by an arrow on the disc (figure 310). The mark must be done by electro pen only in an area between $\emptyset 111$ and $\emptyset 90$. The cover sheet must be fulfilled - a set of the circulating blades VT.

El. pen.

the marking of the hole $1+$ an arrow (highlighted by orange colour)

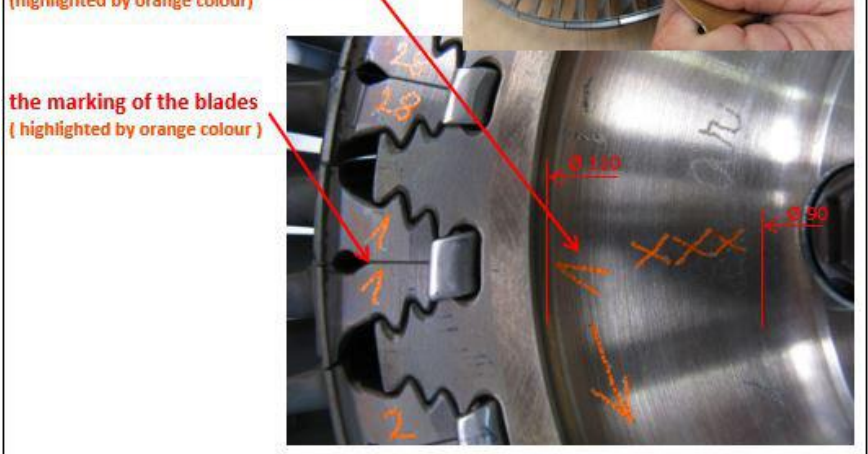

\begin{tabular}{|l|l|l|l|l|}
\hline Tg. zmèna č.: & Platnost: & Rev.: & Vypracoval/Originator & Schválil/Approved \\
Proc Chg. No: & Validity dote: & Rev.: & $\begin{array}{l}\text { Iméno/Name: } \\
\text { Podpis/Signature: }\end{array}$ & $\begin{array}{l}\text { Iméno/Nome: } \\
\text { Podpis/Signoture: }\end{array}$ \\
\cline { 4 - 5 } & & & Datum/Date: & Datum/Date: \\
\cline { 4 - 5 } & & & Revize/Revision: & Oper. č./Oper. No: 220 \\
\hline
\end{tabular}

Figure 3 The designed technological instructions translated into English language

\section{REFERENCES}

[1] ŠŤASTNÝ, Jiř́i a Boleslav TŘEŠTíK. Manuál technické dokumentace. 6. přepracované. České Budějovice: KOPP, 2009. ISBN 97880723235.

[2] Uhnák, J. - Hospodka, J.: Flight Cost Management. In Zvyšovanie bezpečnosti v civilnom a vojenskom letectve - 2007. Žilina: Žilinská univerzita v Žilině Fakulta prevádzky a ekonomiky dopravy a spojov, 2007, s. 111-116. ISBN 978-80-8070-665-4. (in Slovak).

[3] Hospodka, J. - Pleninger, S.: The Impact of Air Traffic on the Atmosphere - The Issue of Airlines Integration in the EU ETS. 1. vyd. Praha: ČVUT v Praze, 2015. 100 s. ISBN 978-80-01-05824-4. (in Czech).

[4] Bugaj, M. - Němec, V. - Rostáš, J.: Maintenance Planning of Special Aircraft Equipment. In GEO Spatial Visions. Žilina: EDIS vydavatelstvo Žilinské univerzity, 2015, p. 13-14. ISBN 978-80-554$1113-2$. 